\title{
IL-2 Immunotherapy to Recently HIV-1 Infected Adults Maintains the Numbers of IL-17 Expressing CD4+ $T\left(T_{H} 17\right)$ Cells in the Periphery
}

\author{
Lishomwa C. Ndhlovu • Elizabeth Sinclair • Lorrie Epling • Qi Xuan Tan • \\ Terence Ho • Aashish R. Jha • Ijeoma Eccles-James • Camilla Tincati • Jay A. Levy • \\ Douglas F. Nixon • Frederick M. Hecht • Jason D. Barbour
}

Received: 21 April 2010 /Accepted: 26 May 2010 /Published online: 23 June 2010

(C) The Author(s) 2010. This article is published with open access at Springerlink.com

\begin{abstract}
Little is known about the manipulation of IL-17 producing $\mathrm{CD} 4+\mathrm{T}$ cells $\left(\mathrm{T}_{\mathrm{H}} 17\right)$ on a per-cell basis in humans in vivo. Previous studies on the effects of IL-2 on IL-17 secretion in non-HIV models have shown divergent results. We hypothesized that IL-2 would mediate changes in IL-17 levels among recently HIV-1-infected adults receiving anti-retroviral therapy. We measured cytokine $\mathrm{T}$ cell responses to CD3/CD28, HIV-1 Gag, and CMV pp65 stimulation, and changes in multiple CD4+ T cell subsets.
\end{abstract}

Electronic supplementary material The online version of this article (doi:10.1007/s10875-010-9432-3) contains supplementary material, which is available to authorized users.

L. C. Ndhlovu $(\bowtie) \cdot$ E. Sinclair • L. Epling • Q. X. Tan • T. Ho •

A. R. Jha $\cdot$ I. Eccles-James $\cdot$ C. Tincati $\cdot$ D. F. Nixon

Division of Experimental Medicine, Department of Medicine,

San Francisco General Hospital,

University of California, San Francisco,

San Francisco, CA, USA

e-mail: lndhlovu@medsfgh.ucsf.edu

J. A. Levy $\cdot$ F. M. Hecht $\cdot$ J. D. Barbour

Department of Medicine, San Francisco General Hospital,

University of California, San Francisco,

San Francisco, CA, USA

E. Sinclair $\cdot$ L. Epling $\cdot$ Q. X. Tan $\cdot$ T. Ho

General Clinical Research Center, Department of Medicine,

San Francisco General Hospital,

University of California, San Francisco,

San Francisco, CA, USA

E. Sinclair $\cdot$ L. Epling $\cdot$ Q. X. Tan $\cdot$ T. Ho

Core Immunology Laboratory, Department of Medicine,

San Francisco General Hospital,

University of California, San Francisco,

San Francisco, CA, USA
Those who received IL-2 showed a robust expansion of naive and total $\mathrm{CD} 4+\mathrm{T}$ cell counts and T-reg counts. However, after IL-2 treatment, the frequency of $\mathrm{T}_{\mathrm{H}} 17$ cells declined, while counts of $\mathrm{T}_{\mathrm{H}} 17$ cells did not change due to an expansion of the CD4+ naïve $\mathrm{T}$ cell population (CD27+CD45RA+). Counts of HIV-1 Gag-specific T cells declined modestly, but CMV pp65 and CD3/CD28 stimulated populations did not change. Hence, in contrast with recent studies, our results suggest IL-2 is not a potent in vivo regulator of $\mathrm{T}_{\mathrm{H}} 17$ cell populations in HIV-1 disease. However, IL-2-mediated T-reg expansions may selectively reduce responses to certain antigen-specific populations, such as HIV-1 Gag.

Keywords Human · T cells $\cdot$ HIV-1 $\cdot$ cytokines

interleukin- 2 interleukin-17 · T-regs $\cdot$ anti-retroviral therapy

\section{Introduction}

Interleukin-17 (IL-17) is primarily secreted by CD4+ $\left(\mathrm{T}_{\mathrm{H}} 17\right)$ cells and plays an important role in host defense by inducing and regulating inflammatory responses [1-7]. We and others have shown that, during HIV-1 and SIV infection, the frequency of $\mathrm{T}_{\mathrm{H}} 17$ cells decrease in both peripheral blood and gut associated lymphoid compartments. This depletion appears to be detrimental to the control of HIV-1/SIV infection [4, 5, 8-13]. In recent reports, this loss of $\mathrm{T}_{\mathrm{H}} 17$ cells in the gut mucosa after SIV or HIV infection may compromise the gut mucosa and lead to microbial translocation and increased immune activation $[10,13-15]$.

Previous studies have evaluated the effects of interleukin-2 (IL-2) on IL-17 secretion in non-HIV models 
and have shown divergent results associating with either increases [1] or constraints [16] on production of $T_{H} 17$ cells $[1-3,16]$. IL-2 has been used in conjunction with antiretrovirals to increase CD4+ T-cell counts in HIV-1 infection, and is approved in some European countries for this purpose [17-30]. The effect of IL-2 administration on $\mathrm{T}_{\mathrm{H}} 17$ cells in humans in vivo is not known.

IL-2 therapy in combination with ART has been shown to lead to elevated levels of CD4 $+\mathrm{T}$ cell counts and T-reg populations, and may exert an important influence on HIV-1 disease progression [30-39]. The results from two recent studies, the ESPRIT and SILCAAT trials were conducted to establish the clinical benefit of IL-2 immunotherapy. These studies suggested that, despite a substantial and sustained increase in the CD4+ cell count, as compared with antiretroviral therapy (ART) alone, IL-2 plus ART therapy yielded no added clinical benefit in either study [40]. It has been suggested elsewhere that, while IL-2 treatment does not associate with the outcome measuring death from any cause, it may have a beneficial effect on the incidence of opportunistic infection [41]. In other studies, clinical benefit has been observed after IL-2 treatment among anti-retroviral naïve patients [42]. Other groups have observed that IL-2 improved immune responses against HIV-1, evidenced as decreased viremia, until IL-2 effects tapered off, with IL-2 helping to maintain CD4+ counts during partial treatment interruption (PTI) studies [43].

We employed the setting of a previously conducted, randomized IL-2 clinical trial in recently HIV-1-infected adults receiving ART, to explore IL-2 as a candidate for the manipulation of IL-17 expression. We also explore the effects of IL-2 immunotherapy on changes to the IFN- $\gamma$, TNF- $\alpha$, and IL-2 T-cell response to HIV-1 Gag and CMV pp65 peptides, and polyclonal stimulation (CD3/CD28 stimulation). Others have shown that therapeutic SIV vaccination in the presence of low-dose IL-2 boosts CD8+ but not CD4+ T cell responses to SIV Gag in chronically SIV infected macaques [36]. The effect of IL-2 in HIV-1 infection on the cytotoxic and noncytotoxic (CNAR) anti-HIV response has also been evaluated, and suggests preservation and expansion of this $\mathrm{T}$ cell mediated mechanism of response [30, 44]. In contrast, others have shown no functional benefit of IL-2 on CTL activity [45], while others have suggested an expansion of responses [46]. Yu et al. have shown proliferative responses of $\mathrm{HIV}-1$ and $\mathrm{CMV}$-specific CD8 $+\mathrm{T}$ cells restored by an in vitro addition of IL-2 [47]. Based on prior studies [16], we hypothesized that IL-2 mediated expansion of T-regs will broadly suppress inflammatory $\mathrm{T}$ cell responses and act as a negative regulator, lowering counts of IL-17 expressing CD4+ $\mathrm{T}$ cells.

\section{Methods}

Study Population Specimens were obtained from persons enrolled in the OPTIONS study of early HIV-1 infection conducted in a university-based research clinic at the University of California, San Francisco. Among those enrolled in OPTIONS, approximately $90 \%$ are within 6 months of acquiring HIV-1 infection [48, 49]. All participants gave written, informed consent using protocols approved by the Committee on Human Research, University of California, San Francisco.

Study Design This study is derived from a randomized clinical trial of IL-2 administration to recently HIV-1 infected human adults who had achieved an HIV-1 RNA level in plasma of $<500$ copies $/ \mathrm{ml}$ on a combination antiretroviral regimen (one protease inhibitor and/or one non-nucleoside reverse transcriptase inhibitor, and at least two nucleoside reverse transcriptase inhibitors) that was initiated within 6 months or less of HIV-1 antibody seroconversion. IL-2 was given subcutaneously (7.5 million units, twice daily) for 5 days at 8-week intervals, with dose adjustments for toxicity. Patients were randomized to receive IL-2 within 4 weeks of achieving an HIV-1 RNA level $<500$ copies $/ \mathrm{ml}$, or to remain on ART alone for the next 48 weeks with an option of receiving IL-2 at the end of this period. This study was approved by the Committee on Human Research at the University of California, San Francisco. All study participants provided written informed consent prior to entering the study. HIV-1-uninfected controls employed in this study were acquired from the Stanford University Blood Bank (Palo Alto, CA, USA).

Samples Peripheral blood was collected by venipuncture in blood collection tubes with acid-citrate-dextrose (Vacutainer, BD Diagnostics, Franklin Lakes, NJ, USA). Peripheral blood mononuclear cells (PBMC) were isolated from whole blood by Ficoll density gradient centrifugation, cryopreserved in fetal calf serum containing $10 \%$ DMSO, and stored at the UCSF AIDS specimen bank.

$T$ Cell Responses Thawed and rested PBMC were stimulated with overlapping peptide pools (all 15mers overlapping by $11 \mathrm{aa}$ ) in the presence of $10 \mu \mathrm{g} / \mathrm{ml}$ Brefeldin A (Sigma Aldrich) for $18 \mathrm{~h}$ at $37^{\circ} \mathrm{C}$. Peptide pools were HIV$1 \mathrm{SF} 2 \mathrm{GAG}(4.8 \mu \mathrm{g} / \mathrm{mL}, 127$ peptides, SynPep) and CMV pp65 $(4.25 \mu \mathrm{g} / \mathrm{mL}, 138$ peptides, SynPep). PBMC from each subject were also stimulated with a combination of plate bound anti-CD3 $(0.3 \mu \mathrm{g} / \mathrm{ml}$, Zymed $)$ and soluble antiCD28 (2.5 $\mu \mathrm{g} / \mathrm{mL}$, BD Pharmingen), and unstimulated cells were run in parallel as a negative control. Following stimulation, PBMCs were treated with $2 \mathrm{mmol} / \mathrm{L}$ EDTA, 
washed in PBS, stained with AARD as described above, then fixed and permeabilized by a 10-min incubation in FACS lyse, and a 10-min incubation in FACS Perm (both from BD Biosciences) before staining with fluorescently labeled antibodies: CD3 and CD8 described above, CD4PE-Texas Red (Invitrogen), IFN- $\gamma$-FITC, IL-2-PE, TNF $\alpha$ Alexa Fluor 700 (all BD Bioscience), and IL-17 Alexa Fluor 647 (eBioscience). Cells were washed, re-suspended in FACS buffer, stored at $4{ }^{\circ} \mathrm{C}$, and run on a customized BD LSR II within $18 \mathrm{~h}$. We defined a $\mathrm{T}$ cell response as a cytokine response to stimulus after subtraction of background signal. Any response with less than 100 events was excluded. A positive response was $0.07 \%$ ( 2 SD higher than responses of HIV-seronegative subjects) or higher. T cell counts reported here were derived by multiplying the fractional size of each $\mathrm{T}$ cell subset by the total, corresponding $\mathrm{CD} 4+$ or $\mathrm{CD} 8+\mathrm{T}$ cell count/uL derived from clinical practice.

Flow Cytometry All samples were run on a customized BD LSR II Flow cytometer within $18 \mathrm{~h}$ of staining. Rainbow beads (Spherotec) were used to standardize instrument settings between runs. At least 300,000 lymphocytes were collected for each sample assayed by CFC and at least 200,000 lymphocytes collected for phenotyping assays. Data was compensated and analyzed by using Flowjo Software (Treestar). The staining and gating strategy for identification of cytokine responses and T-reg cells are shown in supplemental Fig. S1. Tregulatory cell populations were identified as $\mathrm{CD} 3+\mathrm{CD} 4+$ $\mathrm{T}$ cells that express CD25 and FoxP3 and lack expression of CD127 (IL-7 receptor), this population has previously been identified as suppressive in functional assays in a number of studies $[50,51]$.

ELISPOT Assay The ELISPOT assay was used both for the detection of IFN- $\gamma$ and IL-17 secreting cells using IFN- $\gamma$ (Mabtech, Cincinnati, OH, USA) and IL-17 (eBioscience) antibody-paired reagents. Procedures for the ELISPOT analysis were as previously described [52]. In brief, equivalent antigen concentrations were used for HIV-1 peptides and CMV lysates. The optimal concentrations of TLR ligands (Invivogen) used were based on titrated amounts that elicited IFN- $\gamma$ secretion. We employed Staphylococcal Enterotoxin B (SEB) at a concentration of $5 \mu \mathrm{g} / \mathrm{ml}$ (Sigma Aldrich). Soluble anti-CD3 $(0.5 \mu \mathrm{g} / \mathrm{mL}$, clone HIT3 $\alpha$; BD Biosciences) and soluble anti-CD28 $(0.5 \mu \mathrm{g} / \mathrm{mL}$ clone 28.2; BD Biosciences) was used as previously described in the ELISPOT assay [4]. Spot totals for duplicate wells were averaged, and all spot numbers were normalized to numbers of IFN- $\gamma$ spot-forming units (SFU) per $1 \times 10^{5}$ PBMCs. Spot values from medium control wells were subtracted to determine responses to each peptide. Responses $>100$ spots $/ 10^{5}$ PBMCs were considered as a positive responding population.

Statistical Analysis We tested for IL-2-associated changes on test variables by applying the sign rank test to test if the difference between pre- and post-IL-2 administration time periods within each group differed from zero. We compared differences in measurements between groups at baseline and during the post-IL-2 time period with the Wilcoxon two-sample test. We assessed correlations between continuous variables by use of the Spearman rank correlation test. Data were manipulated and statistical tests performed in the SAS System 9.2 for Windows XP. We employed GraphPad/ Prism (La Jolla, CA, USA) to display results from this study.

\section{Results}

Study Population and Description of HAART and IL-2 Therapy

Using HIV-1 as a model to study the effects of IL-2 on IL17 production in vivo, we studied 18 participants from a randomized clinical trial of IL-2 performed at the University of California San Francisco. We restricted selection of IL-2 treated subjects to those who completed at least five cycles (out of a possible six) of IL-2 (Table I). All 18 adults remained on ART for at least 1 year after randomization. Of these 18 subjects, 11 subjects received IL-2 and are referred to as "ART + IL-2." The remaining seven comparison subjects who received ART therapy only during the study period are referred to as "ART." Virologic responses to ART were excellent among all participants who achieved and maintained complete virologic suppression for the duration of the study. We did not observe a viral rebound effect among those who either did or did not receive IL-2. We focused on measures at two time points. Visit 1 was designated at the time when a viral load of less than 500 copies/mL had been achieved on ART, but before IL-2 had been administered in the ART + IL-2 group, and as corresponding time in the ART only group. Visit 2 was approximately 48 weeks later, and represented a time when at least five cycles of IL-2 therapy had been administered in the ART + IL-2, and represented a corresponding time on treatment in the ART alone group.

\section{Characterization of IL-17 Responses}

The elicitation of IL-17 by various mutagens is differentially regulated in mouse and human, and the endogenous factors eliciting IL-17 are poorly characterized [53]. Viral 
Table I Demographic, Clinical, and Laboratory Measures at Study Entry All Patients on Suppressive ART, but Prior to Receipt of Study Drug

\begin{tabular}{|c|c|c|c|c|}
\hline Measurement & $\begin{array}{l}\text { All Subjects } \\
\text { Median (IQR) }\end{array}$ & $\begin{array}{l}\text { ART Only Arm } \\
\text { Median (IQR) }\end{array}$ & $\begin{array}{l}\text { ART + Il-2 Arm } \\
\text { Median (IQR) }\end{array}$ & $P={ }^{\mathrm{b}}$ \\
\hline $\mathrm{N}$ & 18 & 7 & 11 & \\
\hline CD4+T cell count $($ cells $/ \mathrm{mL})$ & $630(525,810)$ & $630(432,810)$ & $630(525,817)$ & 0.7 \\
\hline Viral Load $(\log 10 \mathrm{c} / \mathrm{mL})$ & $2.3(2.3,2.3)$ & $2.3(2.3,2.3)$ & $2.3(2.3,2.3)$ & 1.0 \\
\hline CD8+ T Cell Activation (\% CD38, HLA-DR) & $22.5(15.9,28.9)$ & $21.2(17.2,30.5)$ & $23.7(14.1,28.9)$ & 0.7 \\
\hline Age at Study Entry (Years) & $34(29.3,39.8)$ & $39.4(31.8,39.8)$ & $32.4(28.2,44.4)$ & 0.7 \\
\hline Time From Cohort Entry (Days) & $102(75,133)$ & $105(98,133)$ & $95(69,164)$ & 0.5 \\
\hline Time on Anti-Retroviral Treatment (Days) & $84(56,97)$ & $84(83,87)$ & $82(49,150)$ & 0.8 \\
\hline \multicolumn{5}{|l|}{ Number (Percent) } \\
\hline \multicolumn{5}{|l|}{ Ethnicity } \\
\hline White & $17(94 \%)$ & & & 0.4 \\
\hline Asian & $1(6 \%)$ & & & \\
\hline Hispanic $^{c}$ & $1(6 \%)$ & & & \\
\hline Male Gender & $18(100 \%)$ & & & NA \\
\hline
\end{tabular}

Treatment (ART) is defined as at least two nucleoside reverse transcriptase inhibitors, and either one protease inhibitor (PI), one non-nucleoside reverse transcriptase inhibitor (nnRTI), or both a PI and a nnRTI. This was a first anti-retroviral regimen

${ }^{a}$ Study entry is the time at which individuals were randomized to either receive or not receive IL-2. This randomization occurred after individuals demonstrated complete virologic response to ART within 6 months of starting therapy

${ }^{\mathrm{b}}$ Difference between study groups at first study time-point (Wilcoxon 2 sample test or Fisher's exact)

${ }^{\mathrm{c}}$ May be any race

peptides fail to elicit IL-17 production but may be elicited by other microbial pathogens $[4,6,9,13,54,55]$. To induce consistent IL-17 secretion, we measured the expression of IL-17 in response to various TLR agonists, bacterial components, viral antigens, and polyclonal stimulation to determine the best mitogen to induce reliable IL-17 secretion. We observed robust secretion of IFN- $\gamma$ in response to TLR ligands $1-9$, anti-CD3/CD28mAb mixture, and SEB from PBMCs or sorted CD4 T cells by an ELISPOT assay. Little to no secretion of IL-17 was seen in response to TLR (Toll-like receptor) ligands, viral peptides (Fig. 1a-d), or candidal antigens. Stimulation with either SEB or anti-CD3/CD28 mAb mixture elicited consistent IL-17 secretion (Fig. 1a-d) in overnight cell cultures. This is in line with our previous results and by others showing that differentiation by cytokine polarizing IL-17 induction or pathogens all appear to rely on prior anti-CD3/CD28 elicitation $[4,6,54,56]$. Due to the restricted TCR repertoire of SEB, we elicited IL-17 responses by CD3/ CD28 stimulation. We selected this stimulation for consistency not by use of bacterial or fungal stimuli, whose presence in the periphery during early infection may be very low. Furthermore, consistent with prior reports $[4,5$, 10, 13], IL-17 levels were lower in HIV-infected subjects compared to healthy subjects (Fig. 1a).

Baseline T Cell Responses to Stimuli at Visit 1 (Prior to IL-2 on Both Randomized Populations) We observed that the magnitude of $\mathrm{T}$ cell response cell counts at visit 1 (pre IL-2 trial period) in response to CD3/CD28, HIV-1 Gag, and CMV pp65 peptide pools in the two patient populations did not differ. Thus, the patient groups intended to subsequently receive IL-2 and not receive IL-2 did not differ from one another at baseline and, hence, show evidence the groups were well randomized (Table I).

We observed that IL-17 responses were not induced by viral peptide pool stimulation of $\mathrm{T}$ cells in either CD4+ or CD8+ T cells, but were induced by TCR (anti-CD3/CD28) cross-linking in both groups by $\mathrm{CD} 4+\mathrm{T}$ cells and did not differ between the two groups (Fig. 2).

Changes in the CD4 T Cell Subsets with or without IL-2 Therapy at Visit 2

For those who received ART+IL-2, CD4+ T cell counts increased a median of 1,117 cells/uL (interquartile range (IQR) $(672,1775))$ from baseline but showed much more limited increases in those who received ART alone (median +123 cells/ul (IQR 0, 366)) (Table I, Fig. 3a). CD8+ T cell counts did not increase from baseline for either group ( $p=0.28$ for ART+IL-2 group and $p=0.44$ for ART only group). Frequencies and counts of T-reg cells increased significantly among those who received IL-2, but did not change among those who did not receive IL-2 (Fig. 3b, c). The expanded T-reg cells were primarily of a 
A

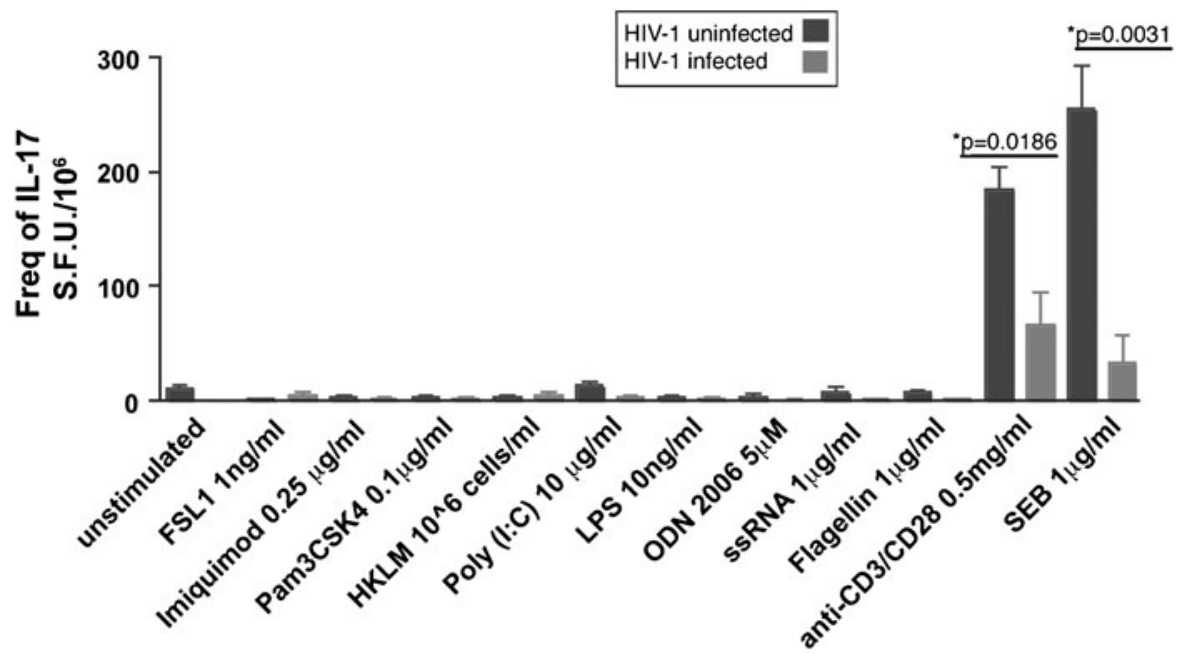

B

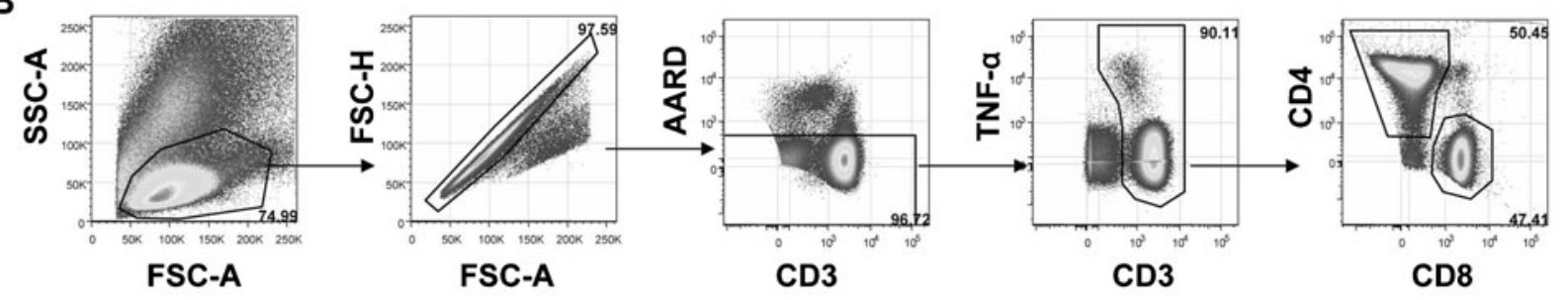

C
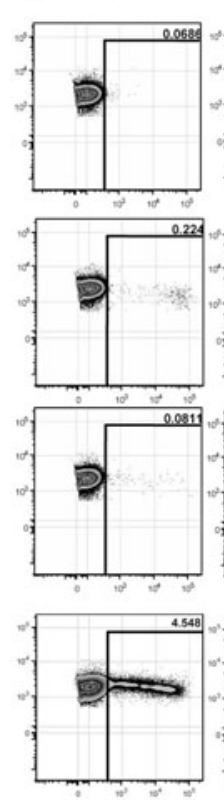

IFN- $\gamma$
CD3+CD4+
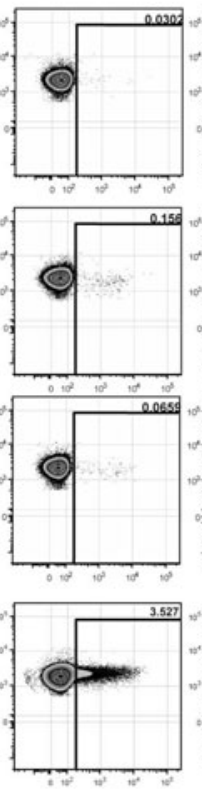

IL-2
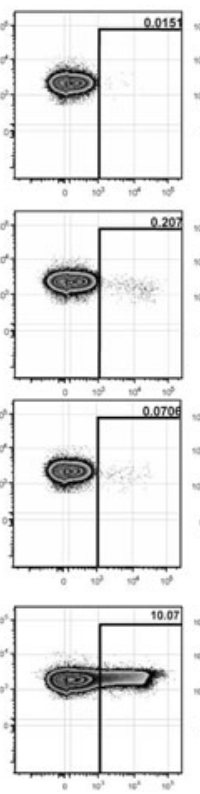

TNF- $\alpha$
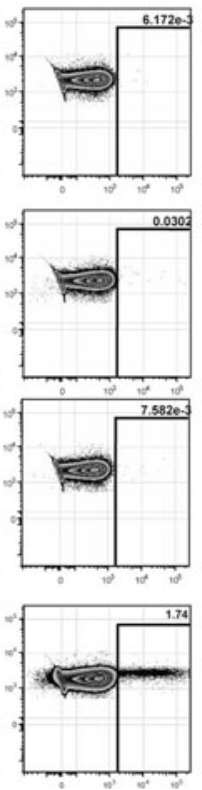

IL-17

Fig. 1 Detection of IL-17 secretion and Flow gating strategy to identify CD4+ and CD8+ Cytokine T cell responses. a Elipsot assay for TLR stimulation HIV-1 uninfected $(n=4)$ and 2 HIV-1infected subjects on IL-2 and 2 subjects without IL-2 $(n=4)$. b Gating strategy for identification of cytokine elicited $\mathrm{T}$ cell responses and of $\mathrm{T}$ regulatory cell subsets. a-d Plots show PBMCs from a representative

D CD3+CD8+
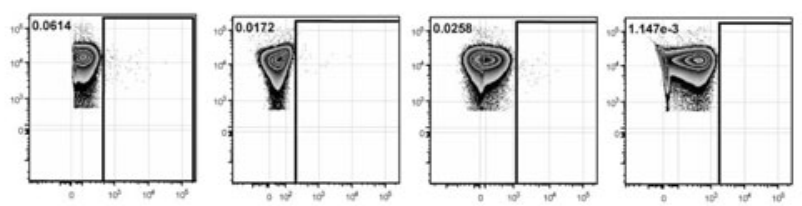

Unstim
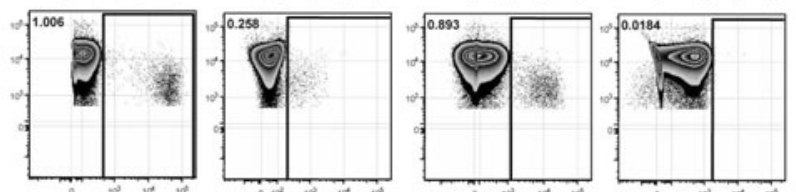

CMV pp65
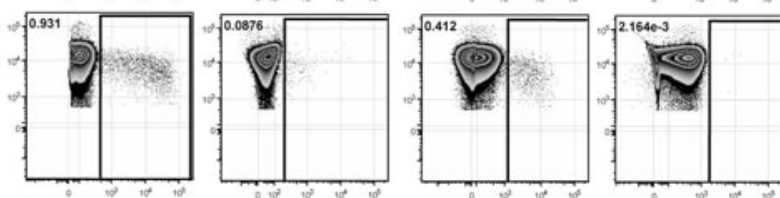

HIV

Gag

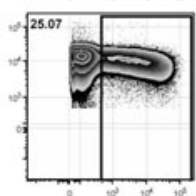

IFN- $\gamma$

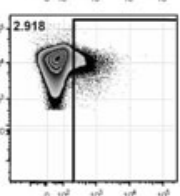

IL-2

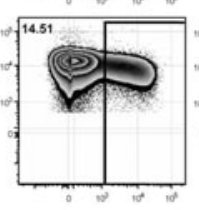

TNF- $\alpha$

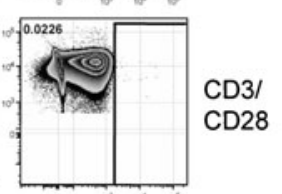

IL-17
HIV-1 infected subject. (See Table I). a-c Intracellular detection of IL-17, IFN- $\gamma$, TNF- $\alpha$, and IL-2 cytokine production elicited by either anti-CD3/CD28 mAb, Gag, or Pp65 peptide pool stimulation by $\mathbf{b}$ CD4+ and c CD8+ T cell subsets. Arrowheads indicated the gated population subsequently analyzed. Fluorescence minus one (FMO) samples were used to define the gates used 
Fig. 2 Counts of T-cell IL-17 responses to $\mathrm{CD} 3 / \mathrm{CD} 28$ and antigen-specific stimulation. On the left-hand side are baseline (visit 1) responses among those who subsequently received ART only (green) and on the righthand side are responses of those who subsequently received ART+IL-2 (orange). Only CD3/ CD28 stimulation of CD4+ T cells elicited an IL-17 response, and the magnitude of CD4+ IL-17 response to $\mathrm{CD} 3 / \mathrm{CD} 28$ did not differ by study group

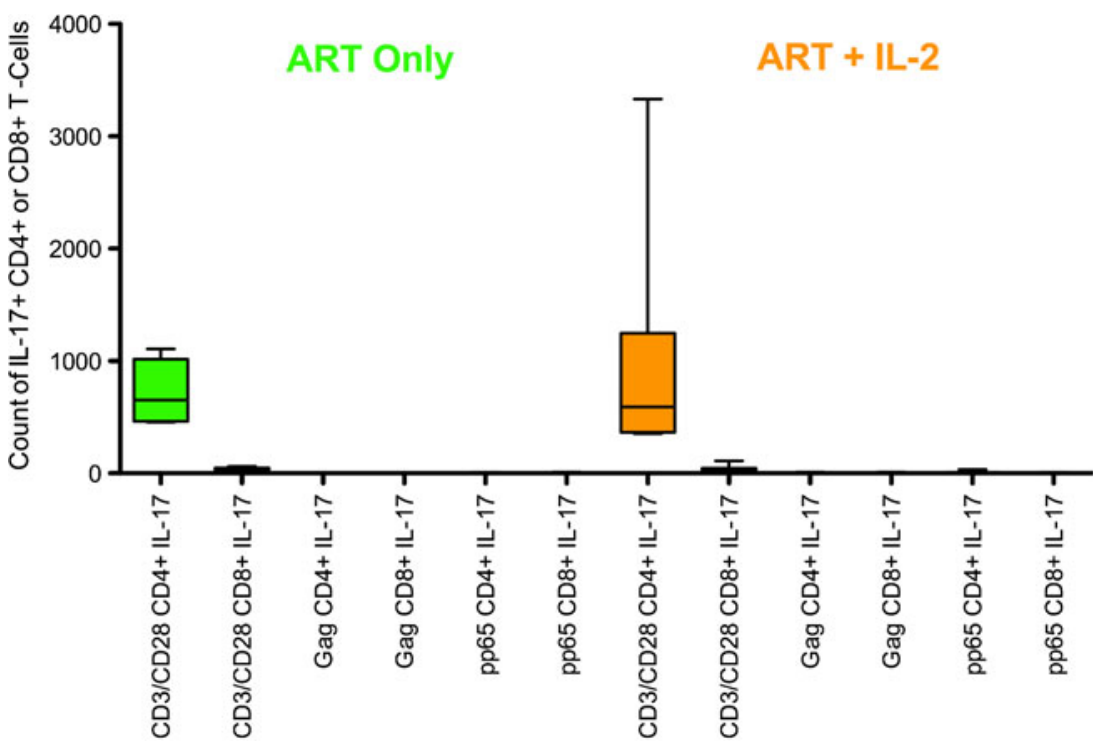

naïve phenotype (FOXP3+CD45RA+ cells) (Sup Figure 1A; Sup Methods). We further examined maturation markers (CD27, CD28, CD45RA) (Sup Methods) on total CD4+ and CD8+ T cells before and after IL-2 administration. We found that the ART+IL-2 treated group experienced a significant and large increase in the frequency of naïve (CD27+ $\mathrm{CD} 28+\mathrm{CD} 45 \mathrm{RA}+) \mathrm{CD} 4+\mathrm{T}$ cell pool $(+10$ percentage points from visit $1, p<0.01$ (Fig. 3d), and experienced a trend towards increase in the naïve $\mathrm{CD} 8+\mathrm{T}$ cell pool $(+5$ percentage points from visit $1, p=0.08)$. To better assess the effects of IL-2 therapy on IL-17 T cell response counts, we analyzed the change in counts from visit 1 (pre-IL-2) to visit 2 (post-IL-2). By examining the degree of change, and not absolute magnitude of change, we aimed to better control for individual variations in baseline responses.

Changes in the $\mathrm{T}_{\mathrm{H}} 17$ Cell Responses with or without IL-2 Therapy at Visit 2

We next measured changes in frequency and counts of cells expressing IL-17 in response to anti-CD3/CD28 stimulation ( $\mathrm{T}$ cells responding to this stimuli may be of any specificity) (Figs. 4 and 5). Among those who received ART+IL-2, we found that responding IL-17 CD4+ T cells, as well as IFN- $\gamma$, IL- 2 , and TNF- $\alpha$, CD4 + T cell responses declined in frequency from visit 1 to visit 2 among those who received ART+IL-2 (Fig. 4), but not for those who received ART alone. CD $8+\mathrm{T}$ cell IFN- $\gamma, \mathrm{TNF}-\alpha$ and polyclonal responses to $\mathrm{CD} 3 / \mathrm{CD} 28$ also declined in frequency, but only among the ART + IL-2 group (Fig. 4).

We next examined changes in CD4+ and CD8+ T cell counts in response to $\mathrm{CD} 3 / \mathrm{CD} 28$. In contrast to the decline in frequency of $\mathrm{T}$ cell responses to $\mathrm{CD} 3 / \mathrm{CD} 28$ in the IL-2- treated group, we found no change in the count of either polyfunctional $\mathrm{T}$ cells or $\mathrm{T}$ cells that expressed only either IL-17 or IFN- $\gamma$ (Fig. 5). However, among the ART+IL-2 group, the counts of $\mathrm{CD} 4+$ (but not $\mathrm{CD} 8+$ ) $\mathrm{T}$ cells that expressed IL-2 or TNF- $\alpha$ increased significantly from baseline for the ART+IL-2 group (Fig. 5). That the frequency of $\mathrm{CD} 3 / \mathrm{CD} 28$ responses declined, while absolute counts either did not decline or in fact increased, may be explained by an expansion of naïve $\mathrm{CD} 4+$ and $\mathrm{CD} 8+\mathrm{T}$ cell populations following IL-2 administration (Fig. 3d for CD4+ data), cell populations that may be unresponsive or only partially responsive to stimuli, as is discussed below.

\section{Changes in HIV Gag Specific and not CMV pp65 CD4+} and CD8+ T Cell Responses with or without IL-2 Therapy

In Fig. 6a, we observe that ART+IL-2 participants showed significant decreases in the counts of Gag-specific CD8+ T Cells expressing IFN- $\gamma$ and TNF- $\alpha$ compared with baseline. In addition, polyfunctional Gag-specific T cells (CD8+ IFN $\gamma+$ IL2 + TNF $\alpha$ T cells and CD4+ and CD8+ IFN $\gamma+\mathrm{TNF} \alpha+\mathrm{T}$ cells) declined from baseline in these participants (Fig. 6a). The frequencies of CD4+ and CD8+ $\mathrm{T}$ cell responses to HIV-1 Gag declined for those who received IL-2 but not for those who received ART alone. The changes are modest in absolute counts, but as these cell responses typically make up only a small faction of total $\mathrm{T}$ cell pools, even these modest declines in counts are likely biologically relevant.

Consistent with prior reports, we found little expression of IL-17 levels in either HIV-1 Gag-specific CD4+ or CD8 $+\mathrm{T}$ cells [4] (Fig. 6a). Among those who received ART+IL-2, we observed general agreement between 
Fig. 3 Changes in CD4+ T cell counts, T-reg cell frequency, and counts in naïve CD4+ T cell counts (maturation profile). $P$ values are the results of sign rank tests comparing visit 1 to visit 2 values (a). The first row shows pre- (visit 1) and postIL-2 (visit 2) study period total CD4+ T cell counts for those who did not receive IL-2 (green) and those who did receive IL-2 (orange) (b). The second row shows pre- (visit 1) and post-IL-2 (visit 2) study period T-regulatory percentages for those who did not receive IL-2 (green) and those who did receive IL-2 (orange) (c). The third row shows pre- (visit 1) and post-IL-2 (visit 2) study period T-regulatory counts for those who did not receive IL-2 (green) and those who did receive IL-2 (orange) (d) Naïve $4 \mathrm{~s}$ increase significantly in proportion $(p<0.005)$ for the ART+IL-2 group. There was no change in the ART only group in naïve $\mathrm{T}$ cell populations by frequency or counts

\section{a ART Only}

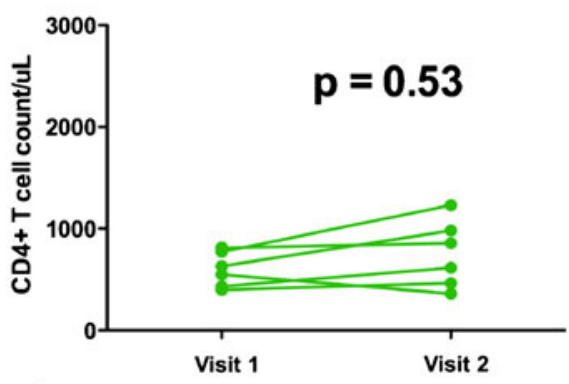

b
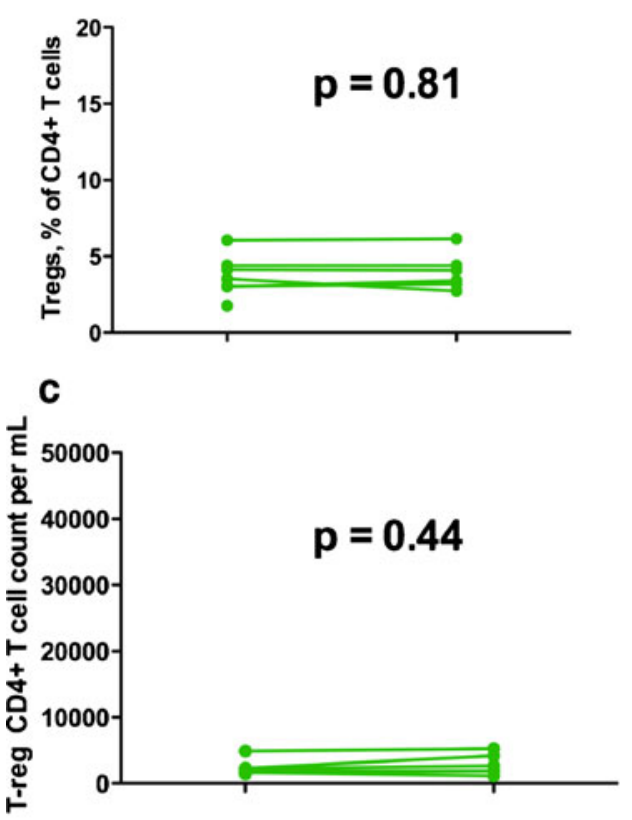

d

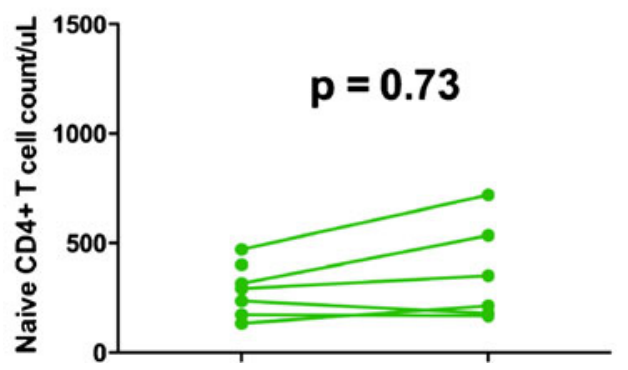

ART + IL-2
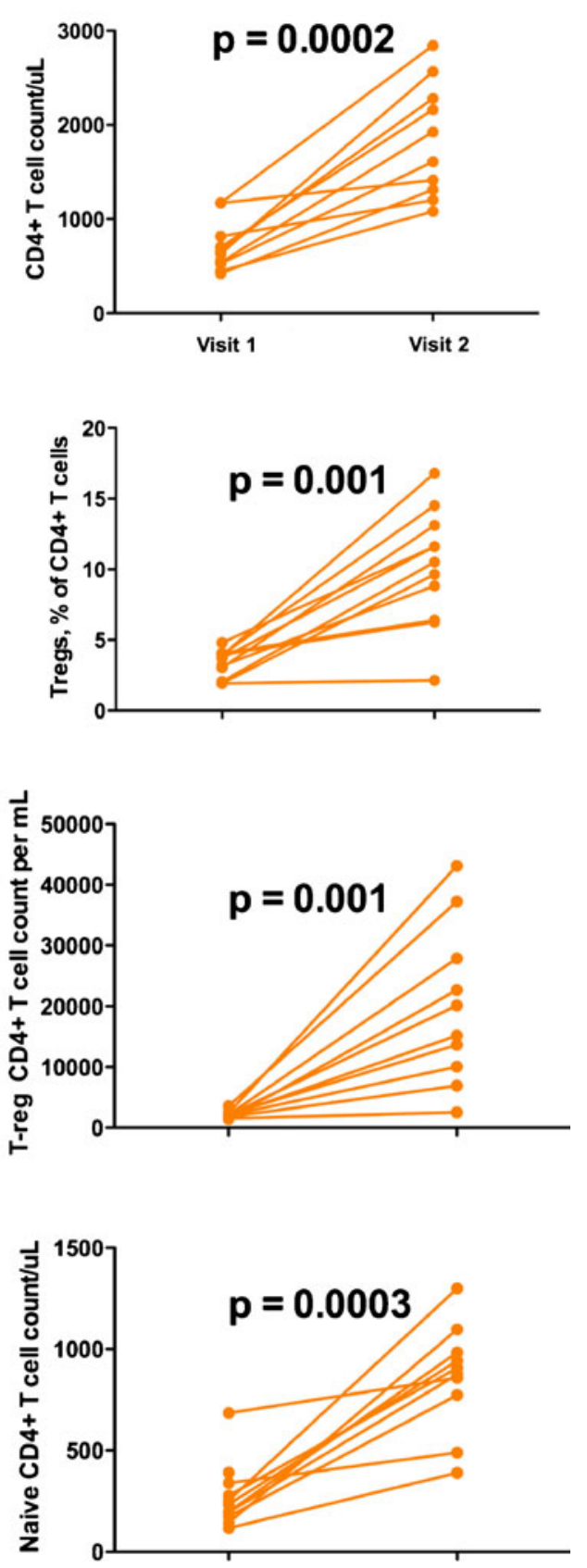

changes in frequencies and changes in counts for HIV-1 Gag CD4+ or CD8+ T cell responses. In contrast to HIV-1 Gag-specific $\mathrm{T}$ cell responses (Fig. 6a), and consistent with findings for CD3/CD28 stimulated T cells (Fig. 4), we found that counts of CMV pp65-specific CD4+ and CD8+ T cells did not change (Fig. 6b) among those who received ART+IL-2. The frequencies of CMV pp65-specific CD4+, but not $\mathrm{CD} 8+\mathrm{T}$ cell responses, declined for those who received ART+IL-2 but not for those who received ART alone.
Relationship of Change in T-reg Frequencies to Change in T Cell Responses to HIV-1 Gag Among Those Who Received ART and IL-2

We observed (Fig. 7) that an increase in T-reg frequency attributable to IL-2 use, among the ART + IL-2 treated group, was associated with declines in IFN- $\gamma$, TNF- $\alpha$ CD 4 $+\mathrm{T}$ cell responses to HIV-1 Gag, tended to associate with IL-2 responses to Gag, but did not associate with changes in IL-17 responses to Gag $(p=0.9)$ 
CD3/CD28 Stimulation, Frequency of Response

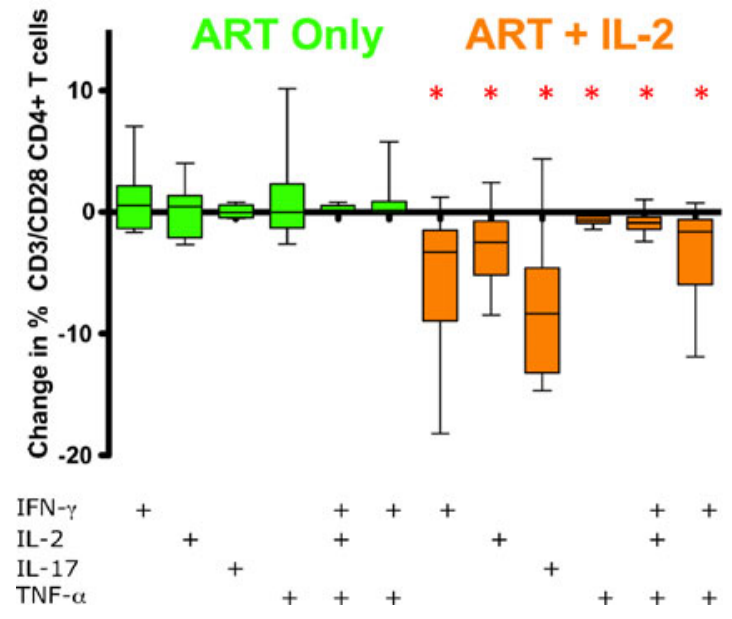

Fig. 4 Change in frequencies of $\mathrm{CD} 3 / \mathrm{CD} 28$ responding $\mathrm{T}$ cells after ART+IL-2: On the left-hand side of Fig. 5 are changes in frequency of $\mathrm{CD} 4+\mathrm{T}$ cell responses to $\mathrm{CD} 3 / \mathrm{CD} 28$ stimulation, and on the righthand side are $\mathrm{CD} 8+\mathrm{T}$ cell responses to $\mathrm{CD} 3 / \mathrm{CD} 28$ stimulation. The ART-only group is shown in green, the group that received ART+IL-2

\section{Discussion}

We observed that administration of IL-2 resulted in no change in the numbers of peripheral blood $\mathrm{T}_{\mathrm{H}} 17$ cells $[1-3$, 16]. IL-2 administration during ART leads to increases in total CD4+ T cell and T-reg populations. Among those who received IL-2, the bulk of the increase in the CD4+ T cell population appeared to be attributable to an expansion of naïve CD4+ T cells (CD27+/CD45A+). Hence, while $\mathrm{T}_{\mathrm{H}} 17$

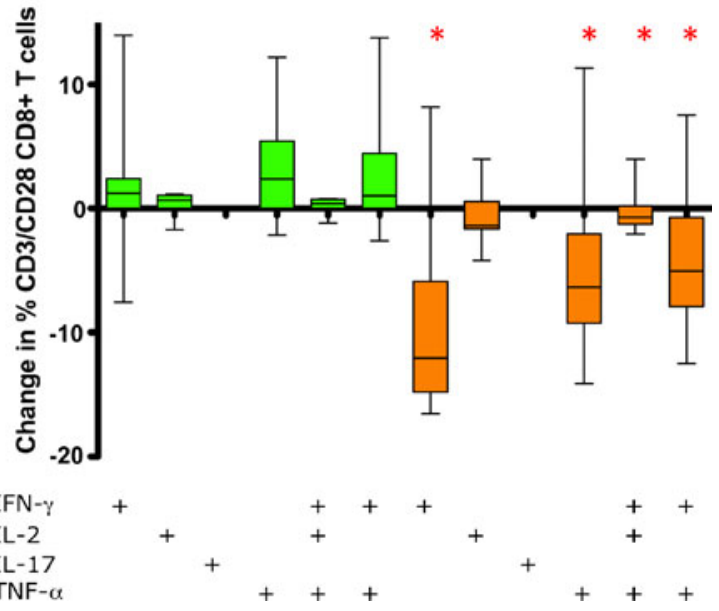

is shown in orange. The frequency of CD4+ and CD8+ T cell responses to $\mathrm{CD} 3 / \mathrm{CD} 28$ stimulation were observed to significantly decrease after IL-2 treatment (ART+IL-2, orange) for multiple cytokine response categories. Asterisks, $p<0.05$ by sign rank test (change from baseline)

counts after IL-2 did not change, IL-2 recipients did experience a decline in the frequency of $\mathrm{T}_{\mathrm{H}} 17$ responses to $\mathrm{CD} 3 / \mathrm{CD} 28$. This effect was likely due to an increase of naïve $\mathrm{CD} 4+\mathrm{T}$ and $\mathrm{CD} 8+$ cells that were not responsive to stimuli, diluting the frequency of $\mathrm{T}_{\mathrm{H}} 17$ cells. Previous reports have suggested IL-2, which expands T-reg populations, may limit IL-17 CD4+ populations [16] in a STAT5dependent manner, which is consistent with our findings. Indeed, taken together, our data suggest IL-2 limits

\section{CD3/CD28 Stimulation, Counts of Response}

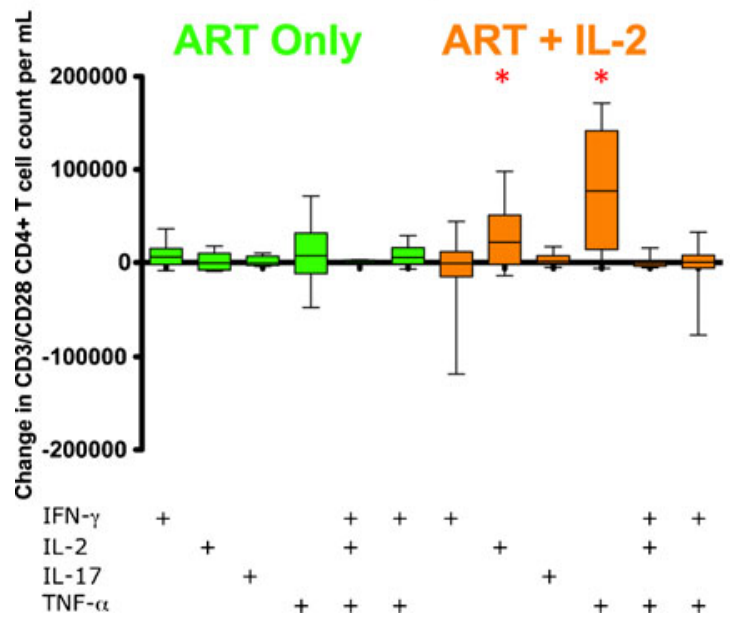

Fig. 5 Change in counts of $\mathrm{CD} 3 / \mathrm{CD} 28$ responding $\mathrm{T}$ cells after ART+IL-2 (a). The data shown are the change from in count from visit 1 to visit 2 counts (calculated as visit 2 values minus visit 1 values). On the left-hand side are changes in counts of CD4+ T cell responses to $\mathrm{CD} 3 / \mathrm{CD} 28$ stimulation, and on the right-hand side are CD8+ $\mathrm{T}$ cell responses to $\mathrm{CD} 3 / \mathrm{CD} 28$ stimulation. The ART-only group is shown in

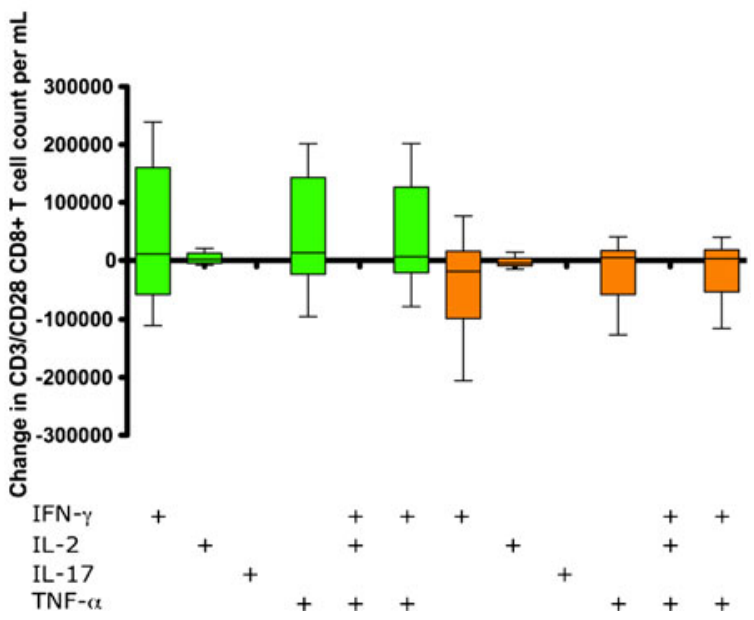

green, the group that received ART+IL-2 is shown in orange. In contrast to frequencies, the counts of CD4+ and CD8+ $\mathrm{T}$ cell responses to $\mathrm{CD} 3 / \mathrm{CD} 28$ stimulation were not observed to decrease after IL-2 treatment (ART+IL-2, orange) for multiple cytokine response categories (asterisks, $p<0.05$ by sign rank test (change from baseline)) 

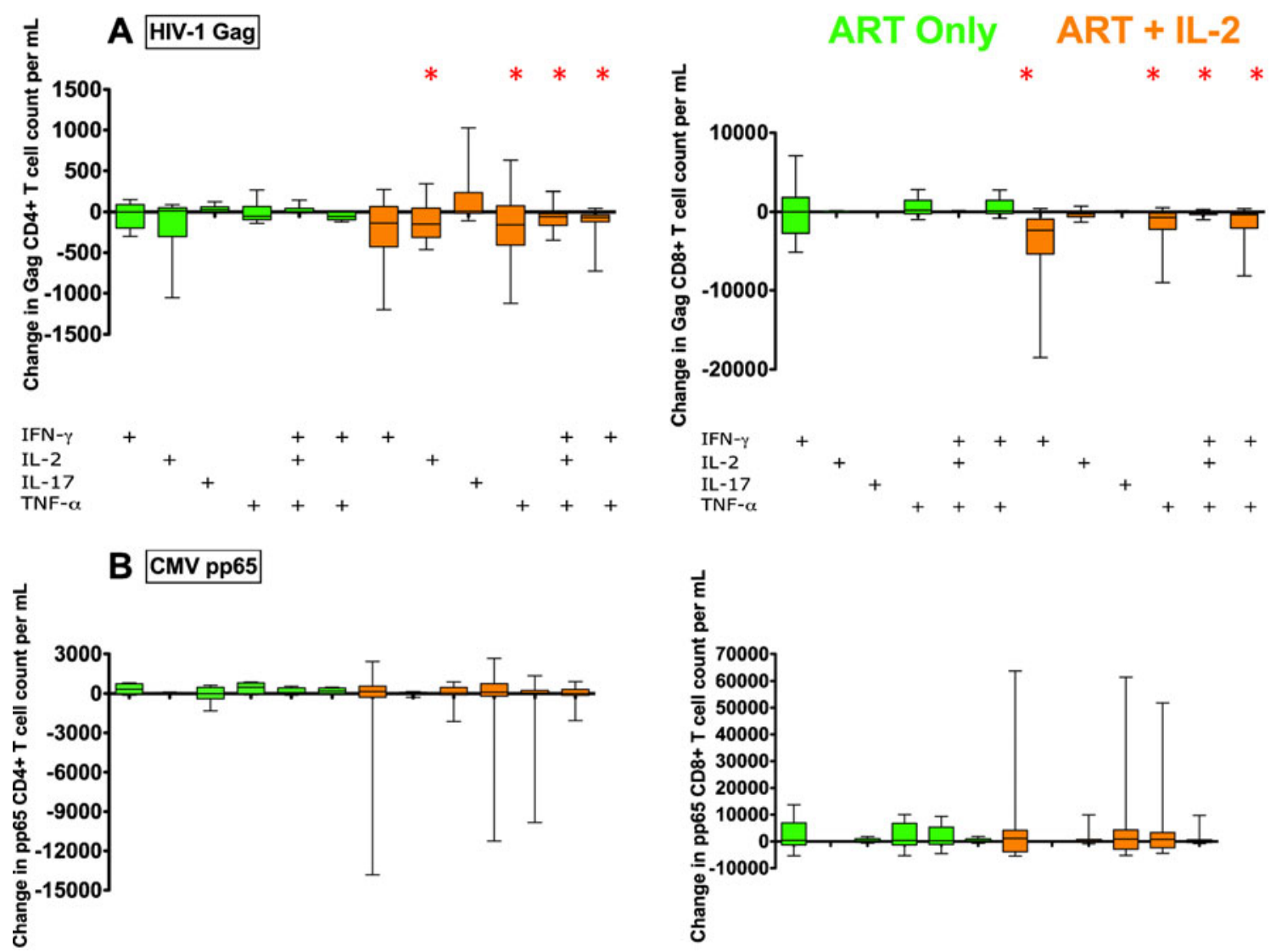

Fig. 6 Decline in counts of Gag responsive T cells for ART+IL-2 and no change in pp65 responding. Data shown is the difference between counts of a HIV-1 Gag and b CMV pp65, T cell responses between pre and post IL-2 treatment (visit 2 counts minus visit 1 counts). On the left-hand side of Fig. 5 are changes in counts of CD4+ T cell

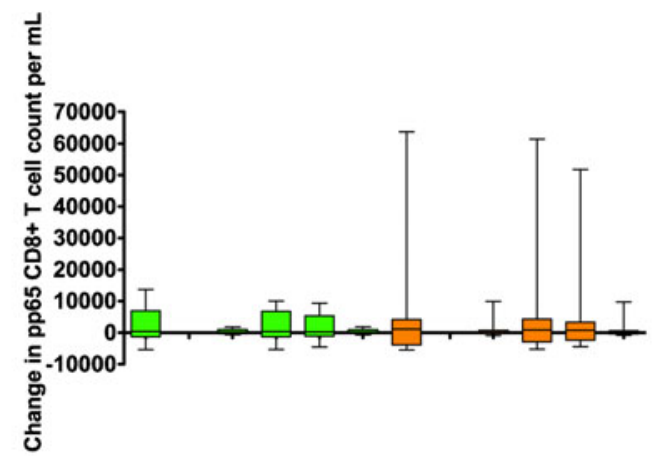

responses to Gag or CMV peptide stimulation, and on the right-hand side are CD8+ T cell responses to Gag or CMV peptide stimulation (asterisks, $p<0.05$ by sign rank test (change from baseline)). More detail may be found in supplementary Fig. 2

Fig. 7 Relationship of Change in CD4+ $\mathrm{T}$ cell cytokine responses to HIV-1 Gag stimulation to change in the frequency of T-reg cells. Change was calculated from pre to post-IL-2 treatment, among the IL-2 treated group only. Correlations are Spearman rank tests. An increase in T-reg frequency was associated with decreases in IFN- $\gamma$, IL-2, and TNF- $\alpha$ responses, but not IL-17 responses
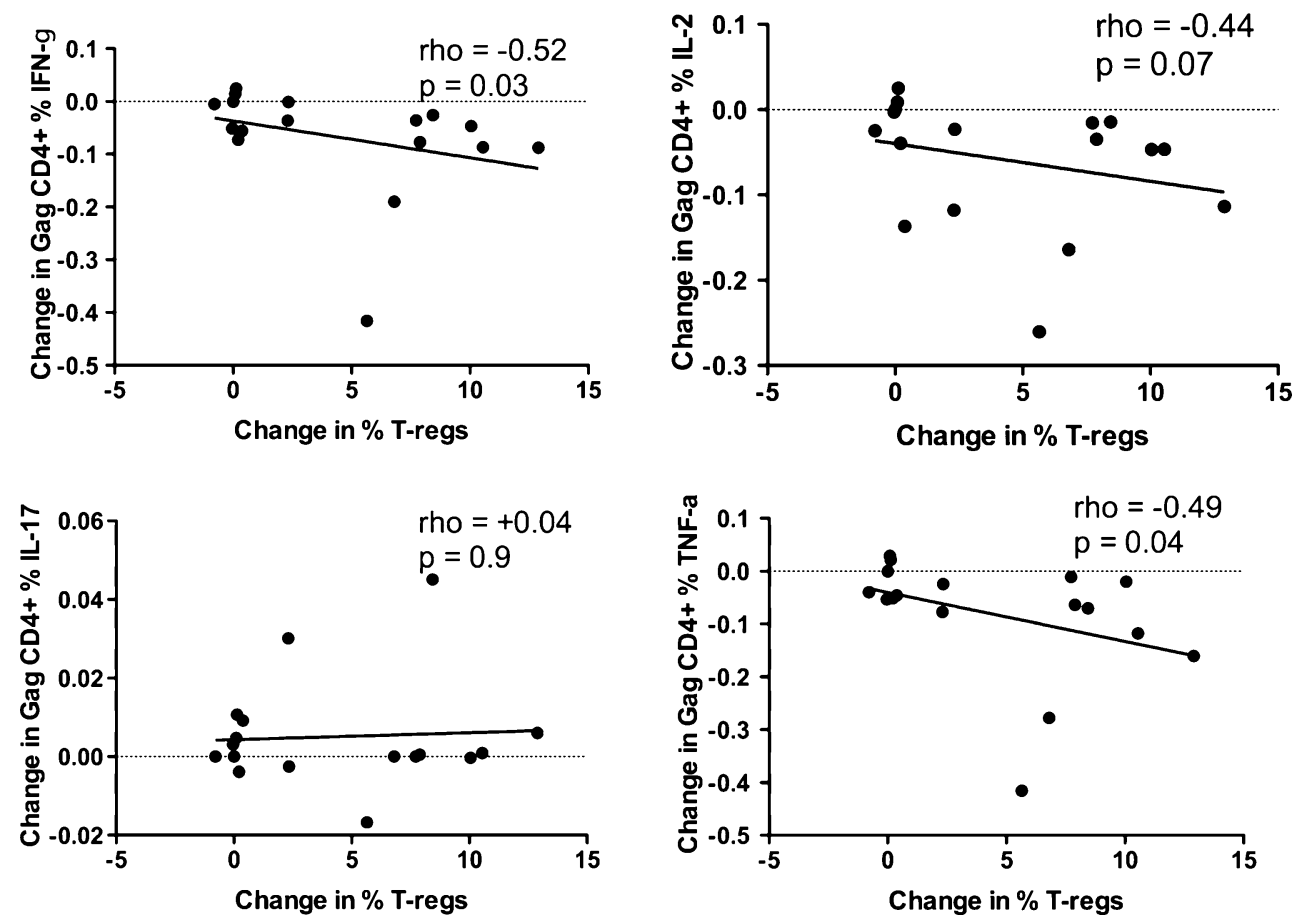
production of - but does not reverse-IL-17 expression in CD4+ T cells in humans.

Among those who received ART and IL-2, we observed modest but significant decreases in counts of CD4+ and CD8+ T cell responses to HIV-1 Gag. Responses to CD3/ CD28 and CMV pp65 stimuli did not change. An expansion of naïve $\mathrm{CD} 4+$ and $\mathrm{CD} 8+\mathrm{T}$ cells appears to have diluted the frequency of $\mathrm{T}$ cells responding to $\mathrm{CD} 3$ / CD28 and CMV pp65 stimuli among the IL-2 recipients. Our findings indicate that the administration of IL-2, and expansion of T-reg populations, was associated with reduction of select $\mathrm{T}$ cell responses, such as suppression of HIV-1 Gag responses, while failing to suppress T cell responses of other specificities, such as CMV pp65. This suppressive activity may have been dependent on the functional profile of the Gag response, rather than upon an antigen-specific T-regulatory response. HIV-1-specific T cell responses have fewer polyfunctional (IFN- $\gamma / \mathrm{TNF}-\alpha$ ) $\mathrm{CD} 8+\mathrm{T}$ cells, being dominated by IFN $-\gamma$ responses. The IL-2 expanded T-reg population may have selectively targeted mono-functional $\mathrm{T}$ cell responses to Gag - that is cell populations expressing only one cytokine, such as IFN- $\gamma$. The specific characteristics of individual antigenspecific populations may render themselves targets for Treg suppressive activity, perhaps by "adaptive" T-regs produced in the periphery and in response to infection. "Adaptive" T-regs are a population of T-regs that may be derived from the total CD4+ T cell pool by a cytokine such as TGF- $\beta$ or IL-2, and act to suppress and regulate antigen specific $\mathrm{T}$ cell responses during infection [57]. Selective reduction of monofunctional $\mathrm{T}$ cell populations by T-regs may ensure balanced expression of cytokines of varying action at the local tissue level.

Our observation of an IL-2-mediated expansion of a naïve CD4+ T cell population that does not mount an IFN$\gamma$ response to polyclonal stimulation is consistent with prior reports by Sereti et al. [60]. We extend these findings by suggesting that IL-2 may expand a population of CD8+ T cells that do not respond to $\mathrm{CD} 3 / \mathrm{CD} 28$ stimulation, nor to antigen-specific stimuli. That said, in contrast to IFN- $\gamma$ and IL-17 responses, the absolute count of CD3/CD28-stimulated CD4+ T cells expressing IL-2 and TNF- $\alpha$ increased significantly from baseline in IL-2-treated participants. The increase in IL-2 may be explained as an effect of upregulation of IL-2 production secondary to exogenous IL-2 administration and stimulation through CD25, the IL-2 receptor. Expanded T-reg populations may have broadly suppressed production of new monofunctional IFN- $\gamma$ responses among the polyclonal $\mathrm{CD} 3 / \mathrm{CD} 28$ responding population, holding that population constant in number, similar to the effect observed for HIV-1 Gag IFN- $\gamma$ responses.

Two recent studies highlight the role of IFN- $\gamma$ in control of T-regulatory cell activity and type- $1 \mathrm{~T}$ cell responses $[58$,
59] in auto-immune models. Some have suggested that IL17 may be negatively regulated by inflammatory cytokines present during HIV-1 infection, such as IFN- $\gamma$ [61]. We observed that the IL-2-mediated expansion of T-regs did associate with a reduction in the IFN- $\gamma$ response to HIV-1 Gag stimulation. Therefore, it bears mention that manipulation of IFN- $\gamma$ via the effects of IL-2 might independently or synergistically modulate select T-regulatory cell subsets. However, in our study, we did not observe a general or broad decline in $\mathrm{T}$ cell IFN- $\gamma$ expression, nor of $\mathrm{T}_{\mathrm{H}} 17$ counts, across stimuli, among IL-2-treated persons.

Alternative strategies to the manipulation of IL-17 levels in humans, including the evaluation of IL- $1 \beta$, IL-23, and IL-6 [62], may be required. That said, the failure of IL-2 to expand IL-17 producing CD4 $+\mathrm{T}$ cells while increasing T-reg populations may augur well for IL-2 use in autoimmunity, diseases characterized by depleted T-reg populations, and elevated IL-17 expression. To achieve expanded T-reg counts and function, as well as increased CD4+ T cell IL-17 expression, might require IL-2 and the added manipulation of ROR- $\gamma$ t [55], IL-6, IL-23, and/or TGF- $\beta$.

As most participants continued on an anti-retroviral regimen after the IL-2 trial had been concluded, our study could not determine if IL-2-mediated expansion of T-regs, and the associated reductions in monofunctional IFN- $\gamma$ expressing Gag T cell responses, will confer any long-term clinical benefit for these persons once they halt treatment. That said, newly expanded T-reg cells may allow suppression of inflammatory $\mathrm{T}$ cell responses, such as those to HIV-1 Gag. These Gag responses are narrow in function, may be ineffective or harmful to the host, perhaps via exaggerated IFN- $\gamma$ levels, in turn suppressing IL-17 and disabling responses to infection [61]. That IL-17 producing $\mathrm{CD} 4+\mathrm{T}$ cell populations, which may be beneficial in HIV1 disease, were not expanded may offset the benefit of a restored T-reg population. Further human trials of the effects on IL-2 on T-reg suppression of select $\mathrm{T}$ cell responses, such as IFN- $\gamma$ and the factors which may expand IL-17 production, may reveal the appropriate balance and function of these regulatory $\mathrm{T}$ cell populations in infection and healthy adults.

Acknowledgements We acknowledge the UCSF/AIDS Research Institute AIDS Specimen Bank (Greenspan), which prepared and stored the viably frozen PBMC aliquots employed here. We thank the staff of the OPTIONS project, and the Division of Experimental Medicine Core Immunology Laboratory. We are deeply appreciative to the OPTIONS study participants for their participation in this trial. We thank Dr. Joseph M. McCune for helpful conversations on this project. This project was supported by grants from the National Institutes of Health; AI066917 (Barbour), AI071713 (Hecht), AI41531 (Levy/Hecht), AI68498 (Nixon). The Core immunology Laboratory and E.S. are supported by grants from the National 
Institutes of Health to the UCSF-GIVI Center for AIDS Research (P30AI027763) and from the National Center for Research Resources (NCRR) to the UCSF CTSI (UL1 RR024131). This publication was supported by NIH/NCRR UCSF-CTSI Grant Number UL1 RR024131-01. The interleukin-2 used in this study was provided by Chiron (Emeryville, CA, USA). Peptide pools were the generous gift of $\mathrm{BD}$, Biosciences.

Open Access This article is distributed under the terms of the Creative Commons Attribution Noncommercial License which permits any noncommercial use, distribution, and reproduction in any medium, provided the original author(s) and source are credited.

\section{References}

1. Amadi-Obi A, Yu CR, Liu X, Mahdi RM, Clarke GL, Nussenblatt $\mathrm{RB}$, et al. TH17 cells contribute to uveitis and scleritis and are expanded by IL-2 and inhibited by IL-27/STAT1. Nat Med. 2007;13:711-8

2. Kryczek I, Wei S, Vatan L, Escara-Wilke J, Szeliga W, Keller ET, et al. Cutting edge: opposite effects of IL-1 and IL-2 on the regulation of IL-17+ T cell pool IL-1 subverts IL-2-mediated suppression. J Immunol. 2007;179:1423-6.

3. Kryczek I, Wei S, Zou L, Altuwaijri S, Szeliga W, Kolls J, et al. Cutting edge: Th17 and regulatory $\mathrm{T}$ cell dynamics and the regulation by IL-2 in the tumor microenvironment. J Immunol. 2007;178:6730-3.

4. Ndhlovu LC, Chapman JM, Jha AR, Snyder-Cappione JE, Pagan M, Leal FE, et al. Suppression of HIV-1 plasma viral load below detection preserves IL-17 producing T cells in HIV-1 infection. Aids. 2008;22:990-2.

5. Yue FY, Merchant A, Kovacs CM, Loutfy M, Persad D, Ostrowski MA. Virus-specific interleukin-17-producing CD4+ T cells are detectable in early human immunodeficiency virus type 1 infection. J Virol. 2008;82:6767-71.

6. Milner JD, Brenchley JM, Laurence A, Freeman AF, Hill BJ, Elias $\mathrm{KM}$, et al. Impaired $\mathrm{T}(\mathrm{H}) 17$ cell differentiation in subjects with autosomal dominant hyper-IgE syndrome. Nature. 2008;452:773-6.

7. Steinman L. A rush to judgment on Th17. J Exp Med. 2008;205: 1517-22.

8. Favre D, Lederer S, Kanwar B, Ma ZM, Proll S, Kasakow Z, et al. Critical loss of the balance between Th17 and T regulatory cell populations in pathogenic SIV infection. PLoS Pathog. 2009;5: e1000295.

9. Prendergast A, Prado JG, Kang YH, Chen F, Riddell LA, Luzzi G, et al. HIV-1 infection is characterized by profound depletion of CD161+ Th17 cells and gradual decline in regulatory $\mathrm{T}$ cells. Aids. 24:491-502.

10. El Hed A, Khaitan A, Kozhaya L, Manel N, Daskalakis D, Borkowsky W, et al. Susceptibility of human Th17 cells to human immunodeficiency virus and their perturbation during infection. J Infect Dis. 201:843-54.

11. Macal M, Sankaran S, Chun TW, Reay E, Flamm J, Prindiville TJ, et al. Effective CD4+ T-cell restoration in gut-associated lymphoid tissue of HIV-infected patients is associated with enhanced Th17 cells and polyfunctional HIV-specific T-cell responses. Mucosal Immunol. 2008;1:475-88.

12. Kader M, Wang X, Piatak M, Lifson J, Roederer M, Veazey R, et al. Alpha4(+)beta7(hi)CD4(+) memory T cells harbor most Th-17 cells and are preferentially infected during acute SIV infection. Mucosal Immunol. 2009;2:439-49.

13. Brenchley JM, Paiardini M, Knox KS, Asher AI, Cervasi B, Asher TE, et al. Differential Th17 CD4 T cell depletion in pathogenic and nonpathogenic lentiviral infections. Blood 2008.
14. Aujla SJ, Dubin PJ, Kolls JK. Th17 cells and mucosal host defense. Semin Immunol. 2007;19:377-82.

15. Raffatellu M, Santos RL, Verhoeven DE, George MD, Wilson RP, Winter SE, et al. Simian immunodeficiency virus-induced mucosal interleukin-17 deficiency promotes Salmonella dissemination from the gut. Nat Med. 2008;14:421-8.

16. Laurence A, Tato CM, Davidson TS, Kanno Y, Chen Z, Yao Z, et al. Interleukin-2 signaling via STAT5 constrains $\mathrm{T}$ helper 17 cell generation. Immunity. 2007;26:371-81.

17. Arno A, Ruiz L, Juan M, Jou A, Balague M, Zayat MK, et al. Efficacy of low-dose subcutaneous interleukin-2 to treat advanced human immunodeficiency virus type 1 in persons with $</=250 /$ microL CD4 T cells and undetectable plasma virus load. J Infect Dis. 1999;180:56-60.

18. Katlama C, Carcelain G, Duvivier C, Chouquet C, Tubiana R, De $\mathrm{Sa} \mathrm{M}$, et al. Interleukin-2 accelerates CD4 cell reconstitution in HIV-infected patients with severe immunosuppression despite highly active antiretroviral therapy: the ILSTIM study-ANRS 082. Aids. 2002;16:2027-34.

19. Farel CE, Chaitt DG, Hahn BK, Tavel JA, Kovacs JA, Polis MA, et al. Induction and maintenance therapy with intermittent interleukin-2 in HIV-1 infection. Blood. 2004;103:3282-6.

20. Marchetti G, Meroni L, Varchetta S, Terzieva V, Bandera A, Manganaro D, et al. Low-dose prolonged intermittent interleukin2 adjuvant therapy: results of a randomized trial among human immunodeficiency virus-positive patients with advanced immune impairment. J Infect Dis. 2002;186:606-16.

21. David D, Nait-Ighil L, Dupont B, Maral J, Gachot B, Theze J. Rapid effect of interleukin-2 therapy in human immunodeficiency virus-infected patients whose CD4 cell counts increase only slightly in response to combined antiretroviral treatment. J Infect Dis. 2001;183:730-5.

22. Davey Jr RT, Chaitt DG, Piscitelli SC, Wells M, Kovacs JA, Walker RE, et al. Subcutaneous administration of interleukin-2 in human immunodeficiency virus type 1 -infected persons. J Infect Dis. 1997;175:781-9.

23. De Paoli P, Zanussi S, Simonelli C, Bortolin MT, D'Andrea M, Crepaldi C, et al. Effects of subcutaneous interleukin-2 therapy on CD4 subsets and in vitro cytokine production in HIV+ subjects. $\mathrm{J}$ Clin Invest. 1997;100:2737-43.

24. Emery S, Capra WB, Cooper DA, Mitsuyasu RT, Kovacs JA, Vig $\mathrm{P}$, et al. Pooled analysis of 3 randomized, controlled trials of interleukin-2 therapy in adult human immunodeficiency virus type 1 disease. J Infect Dis. 2000;182:428-34.

25. Hengge UR, Goos M, Esser S, Exner V, Dotterer H, Wiehler H, et al. Randomized, controlled phase II trial of subcutaneous interleukin-2 in combination with highly active antiretroviral therapy (HAART) in HIV patients. Aids. 1998;12:F225-34.

26. Kovacs JA, Vogel S, Albert JM, Falloon J, Davey Jr RT, Walker $\mathrm{RE}$, et al. Controlled trial of interleukin-2 infusions in patients infected with the human immunodeficiency virus. N Engl J Med. 1996;335:1350-6.

27. Kovacs JA, Baseler M, Dewar RJ, Vogel S, Davey Jr RT, Falloon $\mathrm{J}$, et al. Increases in CD4 T lymphocytes with intermittent courses of interleukin-2 in patients with human immunodeficiency virus infection. A preliminary study. N Engl J Med. 1995;332:567-75.

28. Larsen CS, Ostergard L, Moller BK, Buhl MR. Subcutaneous interleukin-2 in combination with anti-retroviral therapy for treatment of HIV-1-infected subjects. Scand J Infect Dis. 2000;32:153-60.

29. Witzke O, Winterhagen T, Reinhardt W, Heemann U, GrosseWilde H, Kreuzfelder E, et al. Comparison between subcutaneous and intravenous interleukin-2 treatment in HIV disease. J Intern Med. 1998;244:235-40.

30. Levy Y, Durier C, Krzysiek R, Rabian C, Capitant C, Lascaux AS, et al. Effects of interleukin-2 therapy combined with highly active 
antiretroviral therapy on immune restoration in HIV-1 infection: a randomized controlled trial. Aids. 2003;17:343-51.

31. Aandahl EM, Michaelsson J, Moretto WJ, Hecht FM, Nixon DF. Human CD4+ CD25+ regulatory $\mathrm{T}$ cells control T-cell responses to human immunodeficiency virus and cytomegalovirus antigens. J Virol. 2004;78:2454-9.

32. Kinter AL, Hennessey M, Bell A, Kern S, Lin Y, Daucher M, et al. $\mathrm{CD} 25(+) \mathrm{CD} 4(+)$ regulatory $\mathrm{T}$ cells from the peripheral blood of asymptomatic HIV-infected individuals regulate $\mathrm{CD} 4(+)$ and CD8(+) HIV-specific T cell immune responses in vitro and are associated with favorable clinical markers of disease status. J Exp Med. 2004;200:331-43.

33. Eggena MP, Barugahare B, Jones N, Okello M, Mutalya S, Kityo $\mathrm{C}$, et al. Depletion of regulatory $\mathrm{T}$ cells in HIV infection is associated with immune activation. J Immunol. 2005;174:440714.

34. Ndhlovu LC, Loo CP, Spotts G, Nixon DF, Hecht FM. FOXP3 expressing CD127lo CD4+ T cells inversely correlate with CD38+ $\mathrm{CD} 8+\mathrm{T}$ cell activation levels in primary HIV-1 infection. $\mathrm{J}$ Leukoc Biol. 2008;83:254-62.

35. Andersson J, Boasso A, Nilsson J, Zhang R, Shire NJ, Lindback $\mathrm{S}$, et al. The prevalence of regulatory $\mathrm{T}$ cells in lymphoid tissue is correlated with viral load in HIV-infected patients. J Immunol. 2005;174:3143-7.

36. Nacsa J, Edghill-Smith Y, Tsai WP, Venzon D, Tryniszewska E, Hryniewicz A, et al. Contrasting effects of low-dose IL-2 on vaccine-boosted simian immunodeficiency virus (SIV)-specific CD4+ and CD8+ T cells in macaques chronically infected with SIVmac251. J Immunol. 2005;174:1913-21.

37. Losso MH, Belloso WH, Emery S, Benetucci JA, Cahn PE, Lasala MC, et al. A randomized, controlled, phase II trial comparing escalating doses of subcutaneous interleukin-2 plus antiretrovirals versus antiretrovirals alone in human immunodeficiency virus-infected patients with $\mathrm{CD} 4+$ cell counts $>/=350 /$ mm3. J Infect Dis. 2000;181:1614-21.

38. Davey Jr RT, Murphy RL, Graziano FM, Boswell SL, Pavia AT, Cancio M, et al. Immunologic and virologic effects of subcutaneous interleukin 2 in combination with antiretroviral therapy: a randomized controlled trial. Jama. 2000;284:183-9.

39. Sereti I, Sklar P, Ramchandani MS, Read SW, Aggarwal V, Imamichi $\mathrm{H}$, et al. CD4+ $\mathrm{T}$ cell responses to interleukin-2 administration in HIV-infected patients are directly related to the baseline level of immune activation. J Infect Dis. 2007;196:677-83.

40. Abrams D, Levy Y, Losso MH, Babiker A, Collins G, Cooper DA, et al. Interleukin-2 therapy in patients with HIV infection. $\mathrm{N}$ Engl J Med. 2009;361:1548-59.

41. Sellier P, Lafuente-Lafuente C, Bergmann JF. Interleukin-2 therapy in patients with HIV infection. N Engl J Med. 362:270-1; author reply 271 .

42. Tincati C, Meroni L, Bellistri G, et al. Effects of immunoadjuvant therapy with IL-2 in HIV-positive HAART-naive patients in advanced stage of disease: a characterization of the divere immunological responses to IL-2. 11 th European AIDS Conference/European AIDS Clinical Society. Madrid, 2007.

43. Porter BO, Anthony KB, Shen J, Hahn B, Keh CE, Maldarelli F, et al. Inferiority of IL-2 alone versus IL-2 with HAART in maintaining CD4 $\mathrm{T}$ cell counts during HAART interruption: a randomized controlled trial. Aids. 2009;23:203-12.

44. Read SW, Higgins J, Metcalf JA, Stevens RA, Rupert A, Nason MC, et al. Decreased CD127 expression on T Cells in HIV-1-infected adults receiving antiretroviral therapy with or without intermittent IL-2 therapy. J Acquir Immune Defic Syndr. 2006;42:537-44.

45. Valdez H, Mitsuyasu R, Landay A, Sevin AD, Chan ES, Spritzler $\mathrm{J}$, et al. Interleukin-2 Increases CD4+ lymphocyte numbers but does not enhance responses to immunization: results of A5046s. J Infect Dis. 2003;187:320-5.

46. Imami N, Hardy GA, Nelson MR, Morris-Jones S, Al-Shahi R, Antonopoulos $\mathrm{C}$, et al. Induction of HIV-1-specific $\mathrm{T}$ cell responses by administration of cytokines in late-stage patients receiving highly active anti-retroviral therapy. Clin Exp Immunol. 1999;118:78-86.

47. Yu J, Chen H, Horton H, Bansal A, McElrath JM, Reichman R, et al. Interleukin-2 reconstitutes defective human immunodeficiency virus (HIV), and cytomegalovirus (CMV) specific CD8+ T cell proliferation in HIV infection. J Med Virol. 2006;78:1147-57.

48. Barbour JD, Hecht FM, Wrin T, Segal MR, Ramstead CA, Liegler $\mathrm{TJ}$, et al. Higher CD4+ T cell counts associated with low viral pol replication capacity among treatment-naive adults in early HIV-1 infection. J Infect Dis. 2004;190:251-6.

49. Kothe D, Byers RH, Caudill SP, Satten GA, Janssen RS, Hannon $\mathrm{WH}$, et al. Performance characteristics of a new less sensitive HIV-1 enzyme immunoassay for use in estimating HIV seroincidence. J Acquir Immune Defic Syndr. 2003;33:625-34.

50. Seddiki N, Santner-Nanan B, Martinson J, Zaunders J, Sasson S, Landay A, et al. Expression of interleukin (IL)-2 and IL-7 receptors discriminates between human regulatory and activated T cells. J Exp Med. 2006;203:1693-700.

51. Liu W, Putnam AL, Xu-Yu Z, Szot GL, Lee MR, Zhu S, et al. CD127 expression inversely correlates with FoxP3 and suppressive function of human CD4 $+\mathrm{T}$ reg cells. J Exp Med. 2006;203:1701-11.

52. Meiklejohn DA, Karlsson RK, Karlsson AC, Chapman JM, Nixon DF, Schweighardt B. ELISPOT cell rescue. J Immunol Methods. 2004;288:135-47.

53. Chen Z, O'Shea JJ. Th17 cells: a new fate for differentiating helper T cells. Immunol Res. 2008;41:87-102.

54. Acosta-Rodriguez EV, Rivino L, Geginat J, Jarrossay D, Gattorno M, Lanzavecchia A, et al. Surface phenotype and antigenic specificity of human interleukin 17-producing $\mathrm{T}$ helper memory cells. Nat Immunol. 2007;8:639-46.

55. Ivanov II, McKenzie BS, Zhou L, Tadokoro CE, Lepelley A, Lafaille JJ, et al. The orphan nuclear receptor RORgammat directs the differentiation program of proinflammatory IL-17+ T helper cells. Cell. 2006;126:1121-33.

56. Chen Z, Tato CM, Muul L, Laurence A, O'Shea JJ. Distinct regulation of interleukin-17 in human $\mathrm{T}$ helper lymphocytes. Arthritis Rheum. 2007;56:2936-46.

57. Bluestone JA, Abbas AK. Natural versus adaptive regulatory $\mathrm{T}$ cells. Nat Rev Immunol. 2003;3:253-7.

58. Hu X, Ivashkiv LB. Cross-regulation of signaling pathways by interferon-gamma: implications for immune responses and autoimmune diseases. Immunity. 2009;31:539-50.

59. Koch MA, Tucker-Heard G, Perdue NR, Killebrew JR, Urdahl $\mathrm{KB}$, Campbell DJ. The transcription factor T-bet controls regulatory $\mathrm{T}$ cell homeostasis and function during type 1 inflammation. Nat Immunol. 2009;10:595-602.

60. Sereti I, Imamichi H, Natarajan V, Imamichi T, Ramchandani MS, Badralmaa $\mathrm{Y}$, et al. In vivo expansion of CD4CD45RO-CD25 T cells expressing foxP3 in IL-2-treated HIV-infected patients. J Clin Invest. 2005;115:1839-47.

61. Cruz A, Khader SA, Torrado E, Fraga A, Pearl JE, Pedrosa J, et al. Cutting edge: IFN-gamma regulates the induction and expansion of IL-17-producing CD4 T cells during mycobacterial infection. J Immunol. 2006;177:1416-20.

62. Wilson NJ, Boniface K, Chan JR, McKenzie BS, Blumenschein WM, Mattson JD, et al. Development, cytokine profile and function of human interleukin 17-producing helper T cells. Nat Immunol. 2007;8:950-7. 